\title{
The Birth of Mineral Physics at the ANU in the 1970s
}

\author{
Robert Cooper Liebermann
}

Mineral Physics Institute and Department of Geosciences, Stony Brook University, Stony Brook, NY 11794-2100, USA; Robert.Liebermann@stonybrook.edu; Tel.: +1-(631)-766-5711

Received: 20 January 2020; Accepted: 10 February 2020; Published: 12 February 2020

\begin{abstract}
In 1970, I established the first mineral physics laboratory in Australia at the Australian National University (ANU) under the auspices of A.E. (Ted) Ringwood. Over the next six years, we published 25 research papers in peer-reviewed journals, many of them in collaboration with graduate students, Ian Jackson and Leonie Jones. This research was focused on measurements of sound velocities in minerals (and their structural analogues) at high pressures and temperatures, as well as studies of melting and elastic shear instabilities in materials and applications of these experimental data to interpreting seismic models of the Earth's interior.
\end{abstract}

Keywords: mineral physic; ultrasonics; sound velocities; high-pressure phases; melting and elastic shear instabilities

\section{Introduction}

Introduction reproduced with permission from Liebermann [1], published by Elsevier B.V., 2014.

In 1969, when I was a graduate student at Columbia University's Lamont Geological Observatory, my advisor Orson Anderson attended an international conference at the Australian National University (ANU) in Canberra, Australia, to deliver our joint paper on lattice dynamic calculations of the elastic moduli of cubic lattices [2]. This was the meeting at which A.D. Wadsley collapsed on the stage and died while Frank Press was delivering his talk (T. Takahashi, personal communication, March 2013). During that meeting, A.E. (Ted) Ringwood informed Anderson that he was looking for a postdoc to set up an ultrasonics laboratory; subsequently, Richard O'Connell declined to apply for this job and I was offered the post. Enroute from Lamont to Canberra, I spent 10 months as a postdoc at the Seismological Laboratory at Caltech; during that period, I profited from advice and guidance on equipment for my new ultrasonics lab at the ANU from Hartmut Spetzler and Rick O'Connell.

At the Birch Symposium at Harvard in 1970, I met Ted Ringwood and we laid plans to purchase equipment so that it would be on campus when I arrived in late September. John Jaeger (then the Chair of the Department of Geophysics and Geochemistry at the ANU) visited the Anderson lab at Lamont later that year and told me that he hoped I knew how to operate and maintain all that electronic equipment as the ANU did not have suitable staff to do so; that turned out to be apocryphal as the Department not only had an excellent machine shop, but also several very talented electronic staff. In addition, Ringwood and David Green were blessed with two superb Senior Technical Officers, Alan Major and William Hibberson, who were tremendous assets to my new research program.

My six years at the ANU were a fantastic period of exposure to high-pressure geosciences. While I was still at Lamont, Frank Stacey from the University of Queensland was a visiting scientist. In early 1971, Stacey invited me to give a paper at the Australian-New Zealand Association of Science (ANZAS) in Brisbane. Later, he recommended to Ian Jackson and Leonie Jones, both graduates of the Physics Department of the University of Queensland, that they apply for a graduate fellowship to study at the ANU under my supervision. When they arrived to begin their graduate research programs, Ringwood was nervous about their lack of exposure to Earth sciences, so he insisted that they take "remedial" 
courses in the geology department. After both completed introductory geology, Jackson took the 3rd year mineralogy course and topped the class; Ringwood never raised the issue again.

In 1973, the ANU established the Research School of Earth Sciences (RSES) which provided the opportunity for the Department of Geophysics and Geochemistry to move out from under the control of the Research School of Physical Sciences. Anton Hales arrived from the University of Texas at Dallas to become the Founding Director of the RSES; over the next three years, I learned much from Hales about scientific leadership and administration.

\section{Arrival and First Years at the ANU}

In October 1970, my wife Barbara and I arrived in Canberra with our one-year old daughter, Karen in tow. As Ted Ringwood was overseas, David Green welcomed us and installed us in Apt. \#1 of the Garran University flats in the Woden valley. John Cleary led the search for a car, ending in a 2-door Datsun coupe (a little difficult to install a baby carrier in the rear seat).

On one of my first days in the Department of Geophysics and Geochemistry, Prof. Jaeger introduced me to the faculty and students and offered me a yard of ale with instructions to down it in one gulp. The ultrasonic equipment ordered when I was still at Lamont had been delivered, and with the help of electronics specialist, Eddie Penikis, I began to set up the new ultrasonics laboratory.

With Alan Major, we began to learn how to hot-press polycrystalline specimens suitable for ultrasonic measurements of elastic wave velocities, using synthetic powders prepared by Alan and Bill Hibberson [3]. The first specimens were fabricated in a piston-cylinder apparatus at pressures less than $35 \mathrm{kbar}(3.5 \mathrm{GPa})$ and temperatures up top $1200{ }^{\circ} \mathrm{C}$; we initially focused on germanate analogues of silicate mineral phases. We tested the polycrystals in the ultrasonics lab using a polishing jig and specimen holder fabricated in the Department machine shop (both of which are still currently in use in our lab at Stony Brook).

The first velocity experiment at high pressure were conducted in a liquid-media apparatus to 7.5 kbar in laboratory of Mervyn Paterson with assistance of Bill McIntyre; Bill had been assigned by Jaeger to work with me while Jaeger was "wintering" in Northern Hemisphere. Ringwood was very surprised to learn about this assignment but had no basis to object.

The first results on rutile and spinel compounds were obtained by the pulse transmission ("time-of-flight") technique and reported at the IUGG meeting in Moscow, Russia, in August 1970, less than one year after establishing the new ultrasonics lab at the ANU, with technical assistance of new electronics technician Doug Mayson [4]. These "time-of-flight" measurements were collected to 7.5 kbar at room $\mathrm{T}$ and the data at highest $\mathrm{P}$ were taken to represent pore free specimen [4-11].

The next advance in ultrasonics was to employ the pulse superposition technique to obtain more precise measures of travel times to 7.5 kbar. Values reported were those "back-extrapolated" to 1 bar to obtain velocities representative of a pore-free specimen; these data were then compared with results from single crystals in other labs [5,11-14]. In later experiments, the measurements of velocities using the pulse superposition technique were sufficiently precise to allow determination of the pressure derivatives.

\section{Research of Graduate Students Ian Jackson and Leonie Jones}

Ian Jackson initially worked on melting and elastic shear instabilities in alkali halides [15] and engaged in some hard-sphere modeling of melting with Bob Watts of the Research School of Physical Sciences.

Ian later studied the disproportionation of spinels into mixed oxides and revealed the significance of cation configuration and implications for the mantle [16]. and the elastic properties of $\left(\mathrm{Mg}_{x} \mathrm{Fe}_{1-\mathrm{x}} \mathrm{O}\right)$ solid solutions [11].

His PhD dissertation (1976) was entitled "Phase equilibria and elastic properties in silicate analogue systems: studies of melting and polymorphic phase transformations". 
Leonie Jones initially worked on the elastic and thermal properties of fluoride and oxide analogues with the rock salt, fluorite, rutile, perovskite structures [17] and later the elasticity of aluminate, titanate, stannate and germanate compounds with the perovskite structure [18].

Her Ph.D. dissertation (1976) was entitled "High-temperature elastic properties of fluoride and oxide analogues".

\section{Related Research (1971-1976)}

In 1976, I worked on phase equilibria and elastic properties of pyrolite model for the oceanic upper mantle with David Green, who presented our paper at the IUGG international congress in Grenoble, France [19]. Ringwood expressed surprise that I was collaborating with his colleague and competitor when I was working "under the supervision of Ringwood" (Figure 1).

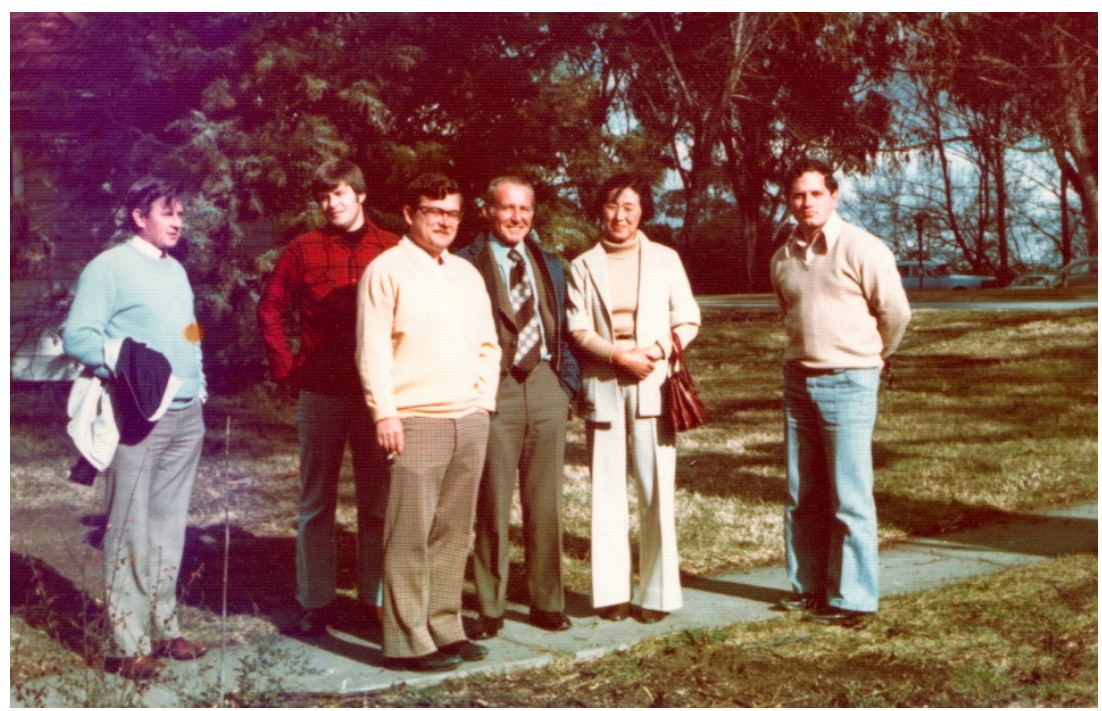

Figure 1. Visit of Professor Syun-iti Akimoto of the University of Tokyo to Research School of Earth Sciences (RSES) in 1975: L to R: David Green, Ted Bence from Stony Brook, Don Anderson from Caltech, Ted Ringwood, Mrs. Akimoto and author.

We also worked on a number of other mineral physics projects:

Elasticity systematics and applications to interpretation of Earth models [5,20-22].

Hot-pressing of polycrystalline specimens of high-pressure phases [23] - presented at 4th International Conference of High Pressure-25-29 November 1974, Kyoto, Japan. See also [24].

Elasticity of anorthite and nature of the lunar crust [25].

Elasticity of stishovite-most challenging project to hot-press and measure sound velocities in polycrystalline stishovite $[9,10]$. No anisotropy observed. Consistent with later Brillouin scattering data from Weidner's laboratory [26].

Elasticity and phase equilibria of spinel disproportion reactions and thermomechanical regime of descending lithospheric plates [16,27].

\section{Interactions with Other Research Groups in the RSES}

I was welcomed into the rock mechanics research group of Mervyn Paterson and Bruce Hobbs. There I met and interacted with Jim Boland and John Fitzgerald, specialists in transmission electron microscopy. I also had extensive contact with John Cleary and others in their seismological group.

As there were no formal courses required for graduate students in the Institute of Advanced Studies at the ANU, I initiated a series of informal seminars on Monday evenings for Ian Jackson and Leonie Jones. In addition to reading and discussing current geophysical literature, we profited from participation of visiting scientists, including Don Anderson, Adam Dziewonski and Ralph 
Lapwood. It was during that era that geophysicists were exploring use of inverse theory to analyze observational data to obtain velocity and density models of the Earth's interior. To help us understand this approach, Prof. Lapwood kindly offered a set of tutorial lectures on inverse theory, using the book by Cornelius Lanzcos.

After arriving in 1973 to become the first Director of RSES, Anton Hales became a regular attendee at our weekly seminars. In addition to bringing his decades of geophysical knowledge, he provided funds for me to buy cheese and crackers to sustain us through the evening (and to leaven the beer which we drank).

When the Department of Geophysics and Geochemistry evolved to become the Research School of Earth Sciences (RSES) in 1973, it became necessary to establish a Faculty Board and produce bylaws; I helped Ian MacDougall to draft these bylaws and we served together on the Faculty Board. During one of the board meetings, some members challenged Director Hales on the appropriateness of his contract with the U. S. Department of Defense (to install and operate seismic stations on the Australian continent); Hales abruptly adjourned the meeting and deputized me to talk to Faculty Board members and convince them that it was Hales' right to hold such a contract.

\section{Post-1970 Research Collaboration between ANU and Stony Brook}

In 1976, I was offered a faculty position as an Associate Professor in the Department of Earth and Space Sciences (later Department of Geosciences) at Stony Brook University and was encouraged by Orson Anderson (my Ph.D. advisor) to accept.

After a postdoctoral appointment in the laboratory of Thomas Ahrens at Caltech, Ian Jackson returned to the ANU in the late 1970s to take up a faculty position in the Petrophysics Group of Mervyn Paterson in the Research School of Earth Sciences.

Jackson and I continued to collaborate on research projects, capitalizing on ultrasonic techniques developed in Jackson's lab at the ANU and synthesis techniques to fabricate polycrystalline specimens of high-pressure phases of mantle minerals developed in my lab at Stony Brook. Gabriel Gwanmesia and Baosheng Li hot-pressed the polycrystals at Stony Brook, and Sally Rigden measured the sound velocities at the ANU during visits by Gwanmesia and the author (Figure 2a,b) [28-34].

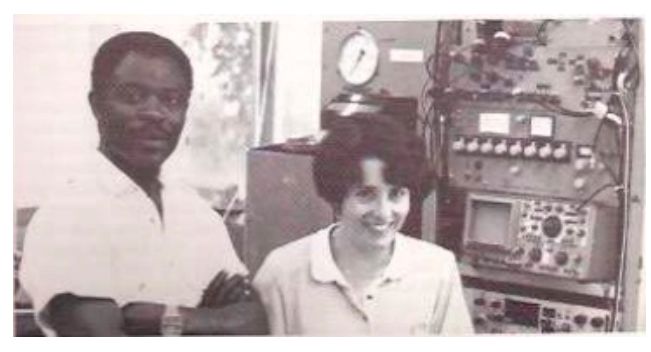

(a)

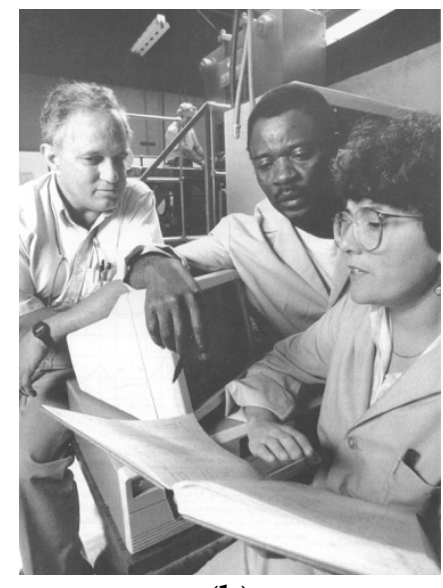

(b)

Figure 2. (a) Gabriel Gwanmesia and Sally Rigden with the ultrasonic interferometer in Ian Jackson's laboratory at the ANU. (b) Sally Rigden from the ANU with Gabriel Gwanmesia and the author in High Pressure Laboratory at Stony Brook in 1991. Reproduced with permission from Liebermann [1], published by Elsevier B.V., 2014.

In 1994, Baosheng Li, then a graduate student and now a Professor in the Department of Geosciences, developed techniques to incorporate ultrasonic interferometric measurements of sound velocities in situ in the Kennedy-Getting high-pressure apparatus in collaboration with Ian Jackson 
(my first graduate student and subsequently the Director of the Research School of Earth Sciences at the ANU; see Figure 3a,b). This pioneering development provided the opportunity to conduct sound velocity experiments to pressures of $10 \mathrm{GPa}$ [35] and was exploited over the next few years by many graduate students and postdocs.

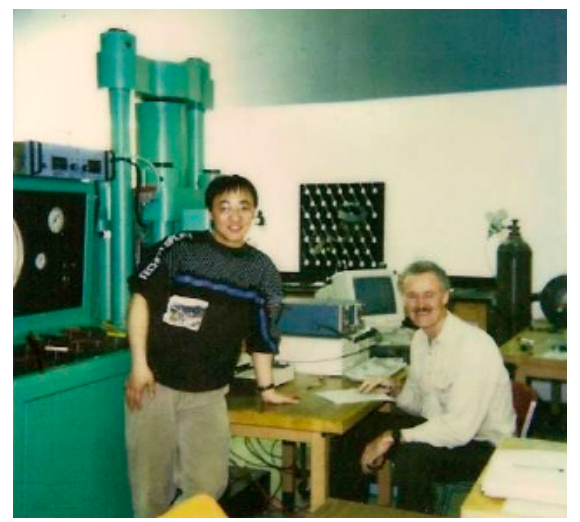

(a)

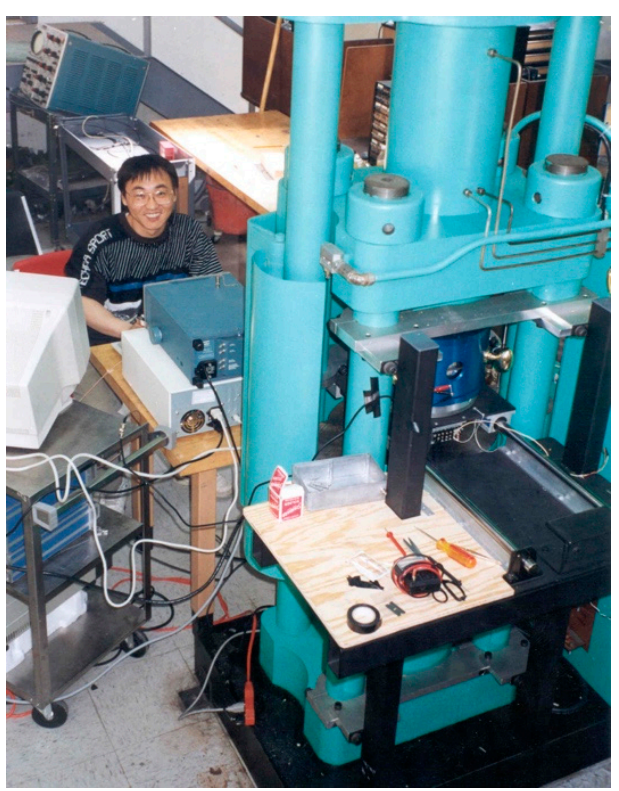

(b)

Figure 3. (a) May 1994. Baosheng Li and Ian Jackson in the Stony Brook High Pressure Laboratory. Ian spent 6 weeks in our laboratory working with Baosheng on interfacing the ANU ultrasonic interferometry system with the 1000-ton split-cylinder apparatus of the Kennedy-Getting type [35]. Reproduced with permission from Liebermann [1], published by Elsevier B.V., 2014. (b) Baosheng Li and Kennedy-Getting press with Walker-type module in High Pressure Lab in 1994. Reproduced with permission from Liebermann [1], published by Elsevier B.V., 2014.

As part of her doctoral research at the ANU, Jennifer Kung spent six months at Stony Brook on the synthesis of polycrystalline specimens of $\mathrm{ScAlO}_{3}$-perovskite with the aid of Gabriel Gwanmesia [36,37]. When she was a postdoctoral research associate at Stony Brook from 2000-2005, Jennifer measured the high-temperature velocities of orthoenstatite in Jackson's lab (Figure 4) [38]; Sytle Antao (graduate student of John Parise) accompanied Jennifer to measure the sound velocities of magnesium ferrite spinel [39]. 


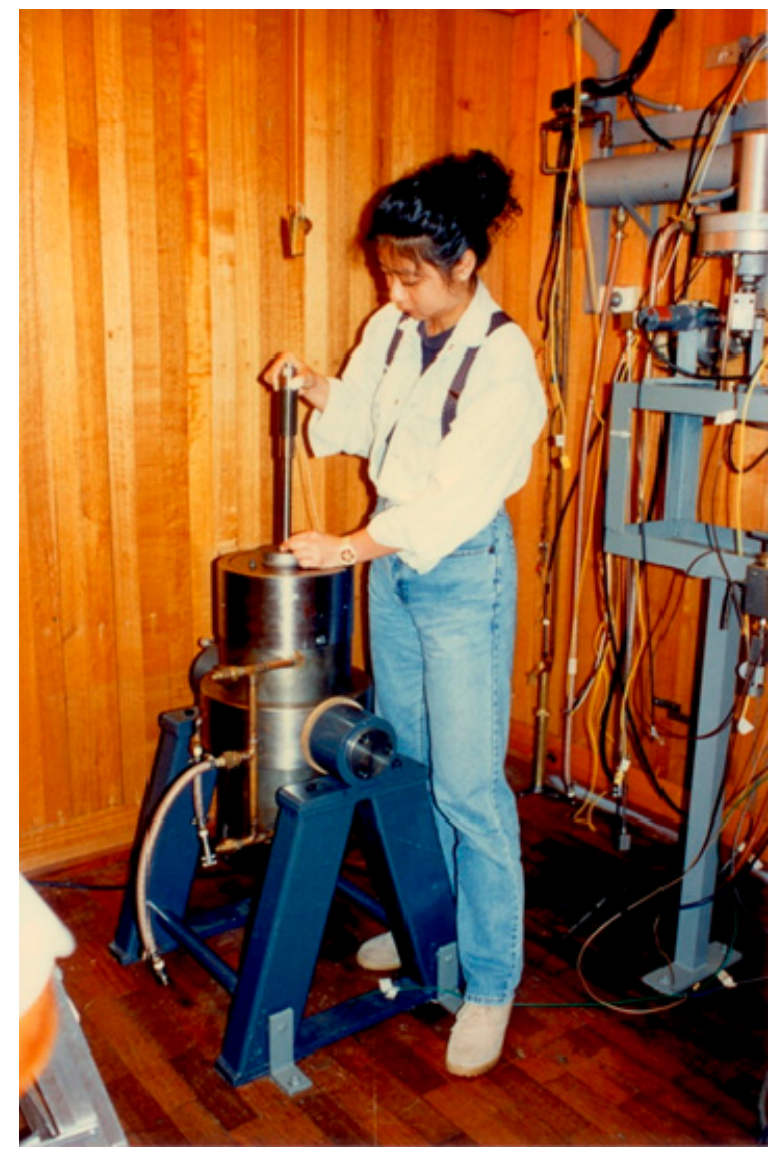

Figure 4. Jennifer Kung with high-temperature, ultrasonic apparatus in laboratory of Ian Jackson at the RSES at the ANU. Circa 2011.

In the most recent collaboration between the ANU and Stony Brook, Ting Chen and her colleagues measured the sound velocities of polycrystalline coesite at high pressure and temperature in Baosheng Li's laboratory [40] using a specimen hot-pressed by the author in a girdle-anvil apparatus in 1975, and so very "well-aged" [23].

In the author's most recent visit to Australia, he and his wife were hosted by Maggie and Ian Jackson at their cottage on Lilli Pilli beach, which we remember fondly from our many family visits there from 1970 to 1976 (Figure 5).

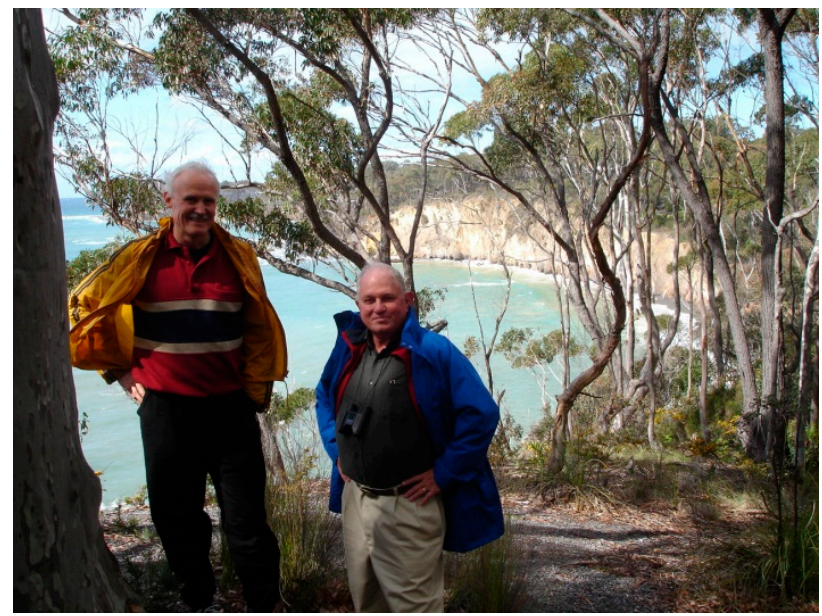

Figure 5. Ian Jackson and the author at Lilli Pilli, Australia, 2006. 
Funding: This paper was written with support from a research grant to Baosheng Li and the author from the National Science Foundation (EAR-1524078).

Acknowledgments: I would like to dedicate this paper to the memory of A.E. (Ted) Ringwood who offered me a research position at the ANU in 1970 and provided technical support and scientific advice over the ensuing 6 years (and, only in exceptional cases, requested to be a co-author). I am grateful to Alan Major, Bill Hibberson and Doug Mayson for their technical contributions to our ultrasonic laboratory and to Ian Jackson and Leonie Jones for their doctoral studies under my supervision. My post-ANU collaboration with Jackson's Petrophysics group was energized by Sally Rigden and Jennifer Kung from the ANU and Gabriel Gwanmesia and Baosheng Li from Stony Brook. I also thank Ian Jackson and Jennifer Kung for their comments and input to early versions of this paper. During my 6 years at the ANU, I maintained an ongoing correspondence with Orson Anderson, my PhD advisor from Columbia University, who kept me up to date on faculty searches in U.S. universities and offered me counsel on which positions might be the best for me on my return to the U.S.

Conflicts of Interest: The author declares no conflict of interest.

\section{References}

1. Liebermann, R.C. The role of serendipity in my career in mineral physics: 1968 to 2013. Phys. Earth Planet. Inter. 2014, 228, 307-323. [CrossRef]

2. Anderson, O.L.; Liebermann, R.C. Equations for the pressure derivatives of the elastic constants for three cubic lattices, and some geophysical applications. Phys. Earth Planet. Inter. 1970, 3, 61-85. [CrossRef]

3. Liebermann, R.C. Elastic properties of minerals determined from ultrasonic or compression data. Phys. Earth Planet. Inter. 1972, 5, 213-217. [CrossRef]

4. Liebermann, R.C. Compressional velocities of polycrystalline olivine, spinel and rutile minerals. Earth Planet. Sci. Lett. 1972, 17, 263-268. [CrossRef]

5. Liebermann, R.C. Elastic properties of germanate analogues of olivine, spinel and beta polymorphs of $(\mathrm{Mg}$, Fe) ${ }_{2} \mathrm{SiO}_{4}$. Nat. Phys. Sci. 1973, 244, 105-107. [CrossRef]

6. Liebermann, R.C. Elasticity of pyroxene-garnet and pyroxene-ilmenite phase transformations in germinates. Phys. Earth Planet. Inter. 1974, 8, 361-374. [CrossRef]

7. Liebermann, R.C.; Mayson, D.J. Elastic properties of polycrystalline diopside $\left(\mathrm{CaMgSi}_{2} \mathrm{O}_{6}\right)$. Phys. Earth Planet. Inter. 1976, 11, 1-4. [CrossRef]

8. Liebermann, R.C. Elasticity of ilmenites. Phys. Earth Planet. Inter. 1976, 12, 5-10. [CrossRef]

9. Liebermann, R.C.; Ringwood, A.E.; Major, A. Elasticity of stishovite. Earth Planet. Sci. Lett. 1976, 32, 129-140. [CrossRef]

10. Liebermann, R.C.; Ringwood, A.E. Some comments on the elasticity of stishovite as determined by ultrasonic and static compression techniques. In High-Pressure Research: Applications in Geophysics; Manghnani, M.H., Akimoto, S., Eds.; Academic Press: New York, NY, USA, 1977; pp. 343-349.

11. Jackson, I.; Liebermann, R.C.; Ringwood, A.E. The elastic properties of $\left(\mathrm{Mg}_{\mathrm{x}} \mathrm{Fe}_{1-\mathrm{x}} \mathrm{O}\right)$ solid solutions. J. Phys. Chem. Miner. 1978, 3, 11-31. [CrossRef]

12. Liebermann, R.C. Elastic properties of polycrystalline $\mathrm{SnO}_{2}$ and $\mathrm{GeO}_{2}:$ Comparison with stishovite and rutile data. Phys. Earth Planet. Inter. 1973, 7, 461-465. [CrossRef]

13. Liebermann, R.C. Elasticity of olivine (a), beta (b) and spinel (g) polymorphs of germanates and silicates. Geophys. J. R. Astron. Soc. 1975, 42, 899-929. [CrossRef]

14. Liebermann, R.C. Elasticity of the ilmenite-perovskite phase transformation in $\mathrm{CdTiO}_{3}$. Earth Planet. Sci. Lett. 1976, 29, 326-332. [CrossRef]

15. Jackson, I.N.S.; Liebermann, R.C. Melting and elastic shear instability of alkali halides. J. Phys. Chem. Solids 1974, 35, 1115-1119. [CrossRef]

16. Jackson, I.N.S.; Liebermann, R.C.; Ringwood, A.E. Disproportionation of spinels into mixed oxides: Significance of cation configuration and implications for the mantle. Earth Planet. Sci. Lett. 1974, 24, 203-208. [CrossRef]

17. Jones, L.E.A.; Liebermann, R.C. Elastic and thermal properties of fluoride and oxide analogues with the rocksalt, fluorite, rutile, perovskite structures. Phys. Earth Planet. Inter. 1974, 9, 101-107. [CrossRef]

18. Liebermann, R.C.; Jones, L.E.A.; Ringwood, A.E. Elasticity of aluminate, titanate, stannate and germanate compounds with the perovskite structure. Phys. Earth Planet. Inter. 1977, 14, 165-178. [CrossRef]

19. Green, D.H.; Liebermann, R.C. Phase equilibria and elastic properties of pyrolite model for the oceanic upper mantle. Tectonophysics 1976, 32, 61-92. [CrossRef] 
20. Liebermann, R.C.; Ringwood, A.E. Birch's law and polymorphic phase transformations. J. Geophys. Res. 1973, 78, 6926-6932. [CrossRef]

21. Liebermann, R.C. On velocity density systematics, polymorphic phase transformations, and the transition zone of the earth's mantle. Comments Earth Sci. Geophys. 1973, 3, 127-133.

22. Liebermann, R.C. Elasticity of the olivine-spinel and olivine-beta phase transformations and the $400 \mathrm{~km}$. discontinuity of the mantle. J. Geophys. Res. 1973, 78, 7015-7017. [CrossRef]

23. Liebermann, R.C.; Ringwood, A.E.; Mayson, D.J.; Major, A. Hot-pressing of polycrystalline aggregates at very high pressures for ultrasonic measurements. In Proceedings of the 4 th International Conference on High Pressure, Kyoto, Japan, 25-29 November 1974; pp. 495-502.

24. Gwanmesia, G.D.; Li, B.; Liebermann, R.C. Hot pressing of polycrystals of high-pressure phases of mantle minerals in multi-anvil apparatus. Pure Appl. Geophys. 1993, 141, 467-484. [CrossRef]

25. Liebermann, R.C.; Ringwood, A.E. Elastic properties of anorthite and the nature of the lunar crust. Earth Planet. Sci. Lett. 1976, 31, 69-74. [CrossRef]

26. Weidner, D.J.; Bass, J.D.; Ringwood, A.E.; Sinclair, E. The single-crystal elastic moduli of stishovite. J. Geophys. Res. 1982, 87, 40-474. [CrossRef]

27. Liebermann, R.C.; Jackson, I.; Ringwood, A.E. Elasticity and phase equilibria of spinel disproportionation reactions. Geophys. J. R. Astron. Soc. 1977, 50, 553-586. [CrossRef]

28. Rigden, S.M.; Jackson, I.N.S.; Niesler, H.; Liebermann, R.C.; Ringwood, A.E. Pressure dependence of the elastic wave velocities for $\mathrm{Mg}_{2} \mathrm{GeO}_{4}$ spinel up to $3 \mathrm{GPa}$. Geophys. Res. Lett. 1988, 15, 605-608. [CrossRef]

29. Gwanmesia, G.; Liebermann, R.C.; Guyot, F. Hot-pressing and characterization of polycrystals of $\beta_{-}-\mathrm{Mg}_{2} \mathrm{SiO}_{4}$ for acoustic velocity measurements. Geophys. Res. Lett. 1990, 17, 1331-1334. [CrossRef]

30. Gwanmesia, G.D.; Rigden, S.; Jackson, I.; Liebermann, R.C. Pressure dependence of elastic wave velocity for $\beta-\mathrm{Mg}_{2} \mathrm{SiO}_{4}$ and the composition of the Earth's mantle. Science 1990, 250, 794-797. [CrossRef]

31. Rigden, S.M.; Gwanmesia, G.D.; FitzGerald, J.D.; Jackson, I.; Liebermann, R.C. Spinel elasticity and seismic structure of the transition zone of the mantle. Nature 1991, 354, 143-145. [CrossRef]

32. Rigden, S.M.; Gwanmesia, G.; Jackson, I.; Liebermann, R.C. Progress in high-pressure ultrasonic interferometry: The pressure dependence of elasticity of high-pressure $\mathrm{Mg}_{2} \mathrm{SiO}_{4}$ polymorphs and constraints on the composition of the transition zone of the Earth's mantle. In High Pressure Research: Applications to Earth and Planetary Sciences; Syono, Y., Manghnani, M.H., Eds.; Terra Scientific Publishing Co.: Tokyo, Japan; American Geophysical Union: Washington, DC, USA, 1992; pp. 167-182.

33. Rigden, S.M.; Gwanmesia, G.D.; Liebermann, R.C. Elastic wave velocities of a pyrope-majorite garnet to 3 GPa. Phys. Earth Planet. Inter. 1994, 84, 35-44. [CrossRef]

34. Li, B.; Rigden, S.M.; Liebermann, R.C. Elasticity of stishovite at high pressure. Phys. Earth Planet. Inter. 1996, 96, 113-127. [CrossRef]

35. Li, B.; Jackson, I.; Gasparik, T.; Liebermann, R.C. Elastic wave velocity measurement in multi-anvil apparatus to 10 GPa using ultrasonic interferometry. Phys. Earth Planet. Inter. 1996, 98, 79-91. [CrossRef]

36. Kung, J.; Rigden, S.; Gwanmesia, G. Elasticity of $\mathrm{ScAlO}_{3}$ at high pressure. Phys. Earth Planet. Inter. 2000, 118, 65-75. [CrossRef]

37. Kung, J.; Rigden, S.; Jackson, I. Silicate perovskite analogue $\mathrm{ScAlO}_{3}$ : Temperature dependence of elastic moduli. Phys. Earth Planet. Inter. 2000, 120, 299-314. [CrossRef]

38. Kung, J.; Jackson, I.; Liebermann, R.C. High-temperature elasticity of polycrystalline orthoenstatite $\left(\mathrm{MgSiO}_{3}\right)$. Am. Mineral. 2011, 96, 577-585. [CrossRef]

39. Antao, S.M.; Jackson, I.; Li, B.; Kung, J.; Chen, J.; Hassan, I.; Liebermann, R.C.; Parise, J.B. High-temperature elasticity of magnesioeferrite spinel. Phys. Chem. Miner. 2007, 34, 345-350. [CrossRef]

40. Chen, T.; Liebermann, R.C.; Zou, Y.; Li, Y.; Qi, X.; Li, B. Tracking silica in Earth's upper mantle using new sound velocity data for coesite to $5.8 \mathrm{GPa}$ and $1073 \mathrm{~K}$. Geophys. Res. Lett. 2017, 44, 7757-7765. [CrossRef]

(C) 2020 by the author. Licensee MDPI, Basel, Switzerland. This article is an open access article distributed under the terms and conditions of the Creative Commons Attribution (CC BY) license (http://creativecommons.org/licenses/by/4.0/). 